\title{
Effect of organic nitrogen and carbon mineralization on sediment organic matter accumulation in fish ponds
}

\author{
Ricardo Jiménez-Montealegre', Marc C J Verdegem², Anne A van Dam ${ }^{3} \&$ Johan A Verreth ${ }^{2}$ \\ ${ }^{1}$ Escuela de Ciencias Biológicas, Universidad Nacional, Heredia, Costa Rica \\ ${ }^{2}$ Fish Culture and Fisheries Group, Wageningen Institute of Animal Sciences, Wageningen University and Research Center, AH \\ Wageningen, The Netherlands \\ ${ }^{3}$ Department of Environmental Resources, UNESCO - IHE Institute for Water Education, DA Delft,The Netherlands
}

Correspondence: M C J Verdegem, Fish Culture and Fisheries Group, Wageningen Institute of Animal Sciences, Wageningen University and Research Center, PO Box 338, 6700 AH Wageningen,The Netherlands. E-mail: marc.verdegem@wur.nl

\begin{abstract}
In aquaculture, ponds with high loads of organic inputs, organic matter accumulates at the bottom over time. Uneaten feed, senescent phytoplankton and faeces are the principal sources of accumulated material, but quantifications are scarce. The sedimented organic matter develops into a flocculent layer in which different processes transform the material into inorganic forms. A better understanding of factors influencing organic matter accumulation/decomposition in the sediment is needed to better understand and manage the dynamics of nitrogen in fish ponds. In this study, the rate of mineralization of organic nitrogen and the nitrogen flux between the sediment and the water column were measured. Organic matter accumulation in fish ponds was quantified, and the data were used to construct, calibrate and validate a dynamic simulation model of organic matter deposition/decomposition in fish ponds. The accumulating material consisted of dead phytoplankton, fish faeces and uneaten feed. Through model calibration, the proportion of these materials in the total accumulated organic matter was determined. In the model, gross photosynthetic rate was estimated from an empirical relationship with feed input. After calibration, the model was validated using independent data. The model simulated well the concentrations of organic carbon and nitrogen in the sediments but it may be developed further, especially by considering the effects of resuspension.
\end{abstract}

Keywords: nitrogen flux, mineralization, organic matter accumulation, fish pond, modelling

\section{Introduction}

Fish production in aquaculture is characterized by high loads of organic matter in the form of feed and/ or organic fertilizers. As a result, organic matter accumulates in pond soils over time (Tucker 1985; Ayub, Boyd \& Teichert-Coddington 1993). In channel catfish ponds, sediment organic matter increased by $0.23 \%$ year $^{-1}$ (Tucker 1985). In sediments of ponds enriched with chicken manure, Ayub and colleagues (1993) reported an increase of organic carbon in the order of $0.1 \%$ month $^{-1}$. At the bottom surface, settled particulate matter develops into a dynamic, flocculent, organic layer (Visscher \& Duerr 1991; Hopkins, Sandifer \& Browdy 1994). With the accumulation of organic matter, the oxygen demand increases and oxygen depletion in the sediments may occur. Aerobic and anaerobic decomposition result in a thin aerobic top layer above a gradually more reduced sediment (Brown, Gowen \& McLusky 1987). The microorganisms in anaerobic soils produce reduced substances such as nitrite, hydrogen sulphide, ferrous iron, and manganese. Ammonia also accumulates in the reduced sediment layer because the biochemical pathway of ammonia transformation requires oxygen. When anaerobic conditions develop in the pond bottom, fish growth is adversely affected because of the formation of toxic substances such as ammonia, nitrite and hydrogen sulfide (Boyd 1990) and because fish avoid grazing in the anaerobic sediments (Avnimelech, Lacher, Raveh \& Zur 1981).

The nitrogen concentration in the sediment is the net result of the deposition of organic nitrogen, the decomposition of the organic matter and the flux be- 
tween the water and the sediments. The main sources of organic nitrogen are uneaten feed, faeces and dead phytoplankton. The amount of uneaten feed is difficult to assess in ponds. For fish cage culture, Phillips, Beveridge and Muir (1985) and Thorpe, Talbot, Miles, Rawlings and Keay (1990) estimated feed spills of $15-30 \%$. In aquarium systems, van der Meer, Herwaarden and Verdegem (1997) found that $21 \%$ of the feed offered to Colossoma macropomum remained uneaten. Boyd (1995) stated that uneaten feed is usually less than $5-10 \%$, but more conclusive measurements are scarce. Faeces generally account for $5-15 \%$ of the nitrogen ingested by fish $(30-40 \%$ being incorporated into fish biomass, $25-80 \%$ excreted as ammonia or dissolved organic nitrogen; Guerin-Ancey 1976; Kaushik 1980; Krom, Porter \& Gordin 1985; Porter, Krom, Robbins, Bricknell \& Davidson 1987; Lovell 1988). Phytoplankton is considered the major source of organic matter in aquaculture ponds (Boyd 1995). Schroeder, Alkon and Laher (1991) found that as much as $50 \%$ of the algal standing crop settles on the sediment surface each day.

A wide range of values for decomposition rates are reported in the literature. Rate constants for decomposition for different algae and aquatic plants varied between 0.03 and 0.20 day $^{-1}$ (Sudo, Aiba \& Mori 1978; Fallon \& Brock 1979). For the decomposition of organic matter in the water column, values in the order of 0.001 to $0.340 \mathrm{mg} \mathrm{N} \mathrm{L}^{-1} \mathrm{day}^{-1}$ are reported (e.g. Harrison 1978; Barat \& Jana 1987). Decomposition rates of organic matter in the sediments varied threefold, ranging from 0.011 to 0.032 day $^{-1}$ (Foree $\&$ McCarty 1970). The flux of nutrients from the sediment into the water column depends on factors such as concentration gradient and bioperturbation, and fluctuates between 0.07 and $6.72 \mathrm{mg} \mathrm{N} \mathrm{L}^{-1}$ day $^{-1}$ (e.g. Krom \& Berner 1980; Schroeder 1987; Blackburn \& Henriksen 1983; Seitzinger 1988; Valdés \& Real 1994). Estimates of total ammonia nitrogen (TAN, $\mathrm{NH}_{3}-\mathrm{N}+\mathrm{NH}_{4}^{+}-\mathrm{N}$ ) flux from marine and freshwater sediments into the overlying water vary between 0.03 and $22 \mathrm{mg} \mathrm{N} \mathrm{m}^{-2}$ day $^{-1}$ (Boynton, Kemp \& Osborne 1980; Brannon, Chen \& Gunnison 1985).

The present study is part of a larger project with the objective to gain more insight into the nitrogen dynamics of feed-driven fish ponds by constructing a dynamic simulation model. Changes in concentrations of $\mathrm{N}$-species in the water column and sediments in earthen fish ponds were modelled (Jiménez-Montealegre, Verdegem, van Dam \& Verreth 2002), but the model was not accurate in predicting the concen- tration of organic matter in the sediments. The objectives of the present study were as follows: (1) to estimate the mineralization rate of organic nitrogen; (2) to measure the flux of inorganic nitrogen forms between sediments and water; (3) to quantify the amount of organic matter accumulating in the sediment of semi-intensively managed fish ponds and (4) to use this information to construct, calibrate and validate a dynamic simulation model of organic matter deposition and decomposition in fish ponds. Such a model will be a useful tool to analyse the effect of various management practices on organic matter accumulation in the sediment, and will lead to a better understanding of factors affecting organic matter accumulation in pond sediments.

\section{Material and Methods}

\section{General}

Three pond experiments were carried out at the 28 Millas Research Station of the Universidad Nacional (UNA) in Limón, Costa Rica. At this site, fish ponds have sandy soils, and water is collected from a nearby wetland. In Experiment 1, the organic nitrogen mineralization rate was measured. In Experiment 2, the flux of organic nitrogen species between water and sediment, and the accumulation of organic matter in pond sediment were quantified. A simulation model for organic matter accumulation and mineralization was then formulated, and the data from Experiment 2 were used for calibration. An independent set of data (Experiment 3) was used for model validation.

\section{Experiment 1}

Four earthen $1.2 \mathrm{~m}$ deep, $800 \mathrm{~m}^{2}$ fish ponds (ponds 710) were stocked with $47.2 \pm 0.1 \mathrm{~g}$ (mean $\pm \mathrm{SD}$ ) C. macropomum at a density of one fish $\mathrm{m}^{-2}$. Fish were fed a $32 \%$ protein pelleted diet at $2 \%$ of the average individual body weight day ${ }^{-1}$, for 90 days. Every fortnight, primary productivity using the light-dark method was measured in each pond. Samples were incubated at two depths $(20$ and $60 \mathrm{~cm})$ for $2 \mathrm{~h}$, and the average gross photosynthetic rate (GPR, $\mathrm{g} \mathrm{C} \mathrm{m}^{-2}$ day $^{-1}$ ) was calculated. A relationship between gross photosynthesis rate and feed input was estimated.

To determine mineralization of organic nitrogen, soil samples from the four ponds were taken using a 
soil corer of $8 \mathrm{~cm}$ diameter and the cores were transported carefully to the laboratory. After dissection of the soil, the undisturbed samples from the top layer $(0-5 \mathrm{~cm})$ were placed in tubes of the same diameter. Water samples taken from three different parts of the pond were mixed, and the mixture were poured carefully over the soil samples for incubation. During the $63 \mathrm{~h}$ incubation period, the water was sampled for TAN every $9 \mathrm{~h}$ and analysed using standard methods (APHA 1989). The initial and final concentrations of organic matter in the soil were determined using the method proposed by Raveh and Avnimelech (1972). The amount of ammonia-nitrogen produced and the loss of organic matter during incubation were used to calculate the mineralization rate constants for nitrogen and carbon.

\section{Experiment 2}

Two $1 \mathrm{~m}$ deep $800 \mathrm{~m}^{2}$ ponds (ponds 1 and 2) were stocked with Oreochromis niloticus at a density of 1.25 fish $\mathrm{m}^{-2}$ for 84 days (Table 2). The initial fish weight was $35.3 \pm 8.6 \mathrm{~g}$ for one pond, and $74.9 \pm$ $20.5 \mathrm{~g}$ for the other. Fish were fed a commercial $30.5 \%$ protein floating pellet at a feeding rate of $2.2 \%$ of the average body weight per day. No water flowthrough was allowed in the ponds, and evaporation and seepage losses were replenished weekly.

Every day at 06:00 and 17:00 hours, dissolved oxygen, water $\mathrm{pH}$ and temperature were measured. Water samples were taken every Tuesday (09:00 hours) at different locations in the ponds, the samples of each pond were mixed and the composite water sample was filtered through a Whatman $\mathrm{GF} / \mathrm{C}$ glass fibre filter and analysed for dissolved $\mathrm{NO}_{3}^{-}-\mathrm{N}, \mathrm{NO}_{2}^{-}$$\mathrm{N}, \mathrm{TAN}$ and alkalinity. Another sample without filtration was analysed for chlorophyll- $a$ in the water column using standard methods (APHA 1989). Each pond was divided into eight sectors of $100 \mathrm{~m}^{2}$ and three soil samples of $6 \mathrm{~cm}$ diameter and $15 \mathrm{~cm}$ deep from each sector were taken every three weeks using a soil corer. One sample was divided into three subsamples (0-5, 6-10 and 11-15 cm depth) and analysed for soil porosity, TAN (trapped and absorbed) and total nitrogen (Kjeldahl) (APHA 1989).

For the determination of inorganic nitrogen fluxes, the other two soil samples were used. The water above the undisturbed soil samples was removed and replaced carefully with $300 \mathrm{~mL}$ of filtered $(0.45 \mu \mathrm{m})$ pond water. Cores were incubated in the dark for $6 \mathrm{~h}$, and the difference between initial and final concen- trations in the water column was used for the determination of flux rates of TAN, $\mathrm{NO}_{2}^{-}-\mathrm{N}^{-}$and $\mathrm{NO}_{3}^{-}-\mathrm{N}$.

At the end of the trial, the ponds were emptied and the final fish weight and fish mortality determined. Proximate whole-body composition was determined at the beginning and at the end of the experiment.

\section{Experiment 3}

Four small stagnant ponds $\left(65 \mathrm{~m}^{2}\right)$ were stocked with C. macropomum of $30 \mathrm{~g} \mathrm{(} \pm 0.5 \mathrm{SD}$ ) (ponds 3-6) at a density of $1 \mathrm{~m}^{-2}$. Fish were fed a $3 \mathrm{~mm}$ dry floating pellets with $35 \%$ crude protein, at a ration of $2.5 \%$ of the average body weight day ${ }^{-1}$. In every pond, accumulated soil organic nitrogen was measured five times during 76 days.

\section{Statistical analysis}

In Experiment 1, a linear regression between TAN and time was estimated. From the initial and final concentration of soil organic matter, a linear relationship was calculated. In both cases, linear regression was used, because this made it easy to estimate the mineralization rate from the slope of each line.

For Experiment 2, the mean values of soil porosity, soil TAN and total nitrogen were compared by repeated measures analysis of variance (ANOVA) with three depths and two ponds as main factors and five sampling periods as the sub-factor (Gomez \& Gomez 1984), with eight cores per pond $(n=240)$. The mean values of fluxes of TAN, $\mathrm{NO}_{2}^{-}$and $\mathrm{NO}_{3}^{-}$were compared also by repeated measures ANOVA with pond as the main factor and sampling period as the sub-factor. When a main effect was significant, pair-wise comparison of treatment means was done by Tukey HSD test $(\alpha=0.05)$. All analyses were carried out using the ANOVA procedure of SAS version 6.12 (SAS Institute, Cary, NC, USA).

\section{Model formulation}

The model includes four state variables: (1) sediment organic nitrogen (s.organic_N); (2) sediment organic carbon (s.organic_C); (3) total ammonia nitrogen in the sediment (s.TAN_sediment) and (4) total ammonia nitrogen in the water column (s.TAN_water) (Fig. 1).

The sources of bottom organic carbon and nitrogen were dead phytoplankton, fish faeces and uneaten feed. Sedimentation rates were related to the 


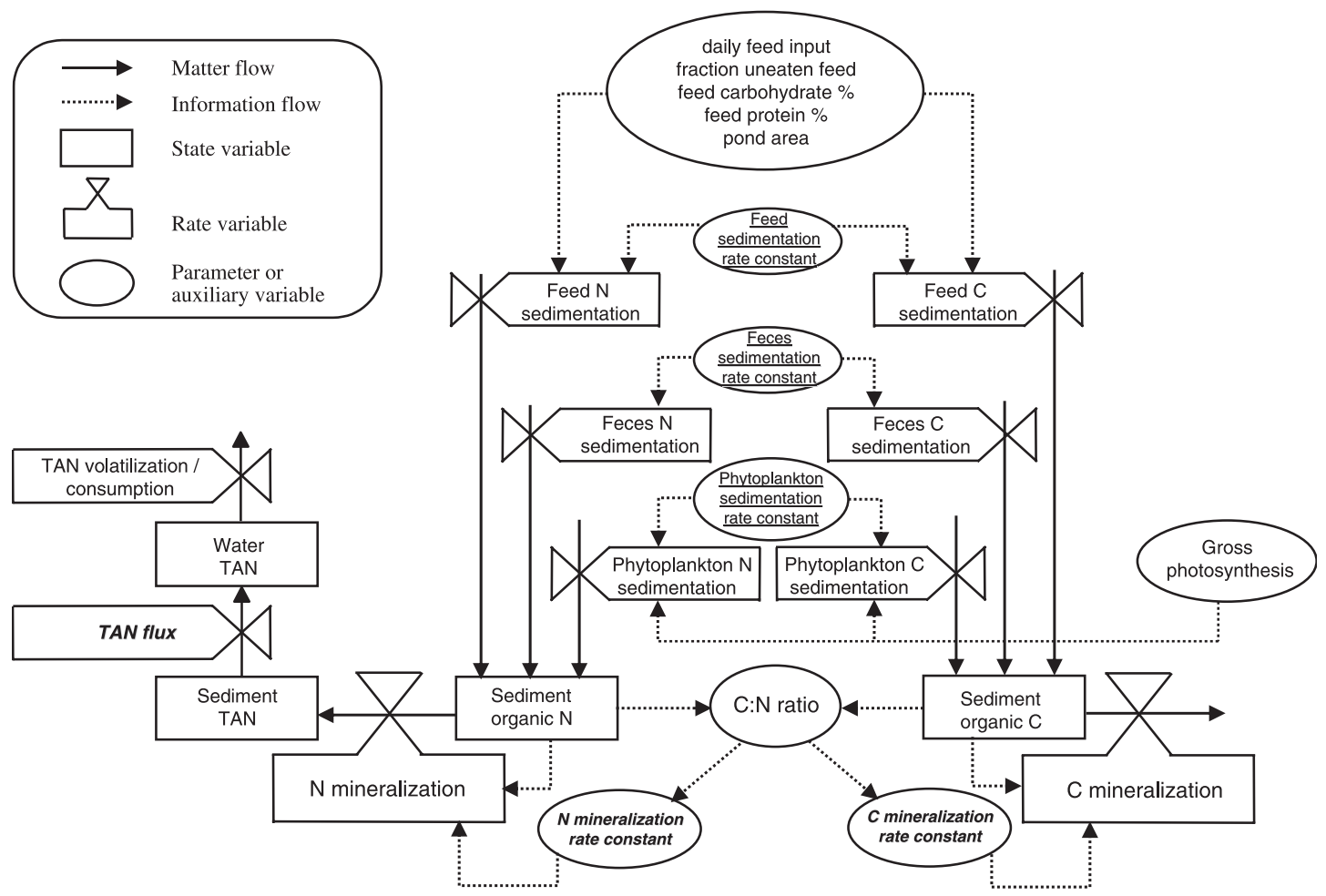

Figure 1 Principal variables and their relations in the model. Calibrated parameters are underlined; measured parameters are in italics. For symbols' explanation, see text.

production rates of these three sources:

$$
\begin{aligned}
& \text { r_c_sedimentation } \\
& =\quad \text { a_c_gross_photosynthesis } \\
& \quad \times \text { p_phyto_sedimentation_rate constant }
\end{aligned}
$$

where r.csedimentation is the sedimentation rate for carbon $\left(\mathrm{m} \mathrm{C} \mathrm{m}^{-2} \mathrm{day}^{-1}\right)$; a.c.gross.photosynthesis the gross photosynthesis rate $\left(\mathrm{mg} \mathrm{C} \mathrm{m}^{-2}\right.$ day $\left.^{-1}\right)$ and p.phyto.sedimentationrate.constant the phytoplankton sedimentation rate constant (-).

Similar equations were defined for the sedimentation rates of nitrogen from phytoplankton and of carbon and nitrogen from faeces and uneaten feed.

The rates of mineralization of organic carbon and nitrogen were modelled as first-order functions based on organic matter concentration:

$$
\begin{aligned}
& \text { r_c_mineralization } \\
&= \text { s_organic_c_soil } \\
& \times \text { p_c_mineralization_rate constant }
\end{aligned}
$$

where r.cmineralization is the mineralization rate for carbon $\left(\mathrm{mg} \mathrm{C} \mathrm{m}^{-2} \mathrm{~d}^{-1}\right)$; s.organic.csoil the organic carbon in soil $\left(\mathrm{mg} \mathrm{C}^{-2}\right)$; p.cmineralizationrate constant the carbon mineralization rate constant $\left(\right.$ day $^{-1}$, Table 1$)$ and

$$
\begin{aligned}
\text { r_n_mineralization } & \\
= & \text { s_organic_n_soil } \\
& \times \text { p_n_mineralization_rate constant }
\end{aligned}
$$

where rnmineralization is the mineralization rate of nitrogen $\left(\mathrm{mg} \mathrm{N} \mathrm{m}^{-2}\right.$ day ${ }^{-1}$ ); s.organicn.soil the organic nitrogen in soil $\left(\mathrm{mg} \mathrm{N} \mathrm{m}^{-2}\right)$; pnmineralizationrate constant the nitrogen mineralization rate constant $\left(\right.$ day $^{-1}$, Table 1$)$.

The rate of mineralization of organic matter decreases with increasing C:N ratio (Alexander 1961). The initial C:N ratio was assumed to be 6.625 :

$$
\begin{aligned}
& \text { p_n_mineralization rate constant } \\
& =\text { if a_CN_ratio }>6.625 \\
& \\
& \quad \text { then } A \text { else } B
\end{aligned}
$$

where the pnmineralization rate constant is the nitrogen mineralization rate constant $\left(\mathrm{d}^{-1}\right)$; a.CNratio $=$ carbon to nitrogen ratio (-); 6.625 the assumed $(-) ; A, B$ the possible values for nitrogen mineralization rate constant and 
Table 1 Parameters settings after model calibration

\begin{tabular}{|c|c|c|}
\hline Parameter* & Value used & Source \\
\hline $\mathrm{P}$ protein digestibility (\%) & 80 & van Dam and Penning de Vries (1995) \\
\hline P carbohydrate digestibility (\%) & 50 & van Dam and Penning de Vries (1995) \\
\hline $\mathrm{P} C$ mineralization rate constant $\left(\right.$ day $\left.^{-1}\right)$ & $3.83-2.68 \times 10^{-5}$ & Experiment 1 (this study) \\
\hline $\mathrm{P} N$ mineralization rate constant $\left(\right.$ day $\left.^{-1}\right)$ & $5.20-3.64 \times 10^{-4}$ & Experiment 1 (this study) \\
\hline $\mathrm{P} \%$ protein in diet (\%) & 30.5 & Experiment $1 / 2$ (this study) \\
\hline $\mathrm{P} \%$ carbohydrate in diet $(\%)$ & 46.6 & Experiment $1 / 2$ (this study) \\
\hline $\mathrm{P}$ maximum gross photosynthesis $\left(\mathrm{gC}^{2}\right.$ day $\left.^{-1}\right)$ & 7.70 & Experiment 1 (feed input vs. chlorophyll-a) \\
\hline $\mathrm{P}$ TAN flux rate constant $\left(\right.$ day $\left.^{-1}\right)$ & $0.10-0.25$ & Experiment 2 (this study) \\
\hline I initial C: $\mathrm{N}$ ratio & $106 / 16$ & Assumed \\
\hline P phytoplankton sedimentation rate constant (-) & 0.20 & Calibration \\
\hline $\mathrm{P}$ faeces sedimentation rate constant $(-)$ & 0.70 & Calibration \\
\hline$P$ feed sedimentation rate constant $(-)$ & 0.90 & Calibration \\
\hline$P$ fraction uneaten $(\%$, from feed offered) & 30 & Calibration \\
\hline
\end{tabular}

*For symbols' explanation, see text.

$$
\begin{aligned}
& \text { p_c_mineralization rate constant } \\
& =\text { if a_CN_ratio }>6.625 \\
& \text { then } C \text { else } D
\end{aligned}
$$

where the p.c.mineralization rate constant is the carbon mineralization rate constant (instant rate, day $^{-1}$ ) and $C, D$ the possible values for carbon mineralization rate constant.

In the model, a.CNratio was calculated from the sediment organic carbon and nitrogen concentrations.

The resulting TAN in the sediments diffuses into the water column if a concentration gradient is formed:

r_tan_flux

$$
=\text { if (s_tan_soil }<\text {; s_tan_water) }
$$

then 0 else $($ s_tan_soil $\times$ p_tan flux_rate constant $)$

where r.tanflux is the rate of TAN flux or diffusion $\left(\mathrm{mg} \mathrm{N} \mathrm{m}^{-2}\right.$ day $^{-1}$ ); s.tan.soil the TAN soil concentration $\left(\mathrm{mg} \mathrm{N} \mathrm{m}^{-2}\right)$ and s.tan.water the TAN water column concentration $\left(\mathrm{mg} \mathrm{N} \mathrm{m}^{-2}\right)$; p.tanfluxrate constant the TAN flux rate constant (s.tan_soil, after calibration, Table 1).

The gross photosynthesis rate was estimated empirically in the model by establishing a relationship between feed input and photosynthesis in Experiment 1. A relational diagram of the model is presented in Fig. 1. Although shown in Fig. 1, volatilization of ammonia-N was assumed to be negligibly small. The principal parameters used in the model are presented in Table 1. The model was implemented in Stella ${ }^{B}$ version 5.1.1. (High Performance Systems, Hanover, NH, USA).

\section{Model calibration}

Data from ponds 1 and 2 (Experiment 2) were used for model calibration. The actual feed input, feed composition (percentage of protein, carbohydrates, dry matter), pond dimensions and fish density used in Experiment 2 were input parameters in the model. Digestibility for protein and carbohydrates were set at $80 \%$ and $50 \%$ respectively (van Dam \& Penning de Vries 1995) (Table 1). To fix the sedimentation rate constants of each of the sources of organic matter (dead phytoplankton, fish faeces and uneaten feed), a range of most probable values was evaluated during calibration. Values for the mineralization of organic carbon and nitrogen ( $A, B, C$ and $D$ in equations (4) and (5)) were also derived through calibration. Using a trial and error procedure, each parameter was changed until the simulated values for sediment organic nitrogen and carbon were within $15 \%$ of the field data.

To assess the agreement between simulated and observed data, the relative error was calculated for each sampling date:

$$
\mathrm{RE}=\frac{\left(S_{\text {Sim }}-S_{\text {obs }}\right)}{0.5\left(S_{\text {Sim }}+S_{\text {obs }}\right)}
$$

where RE is the relative error, $S_{\text {sim }}$ the simulated value of the state variable, $S_{\text {obs }}$ the observed value of the state variable and the average relative error for the whole culture period:

$$
\mathrm{ARE}=\frac{\sum \mathrm{RE}}{n}
$$

where ARE is the average relative error and $n$ the number of observations. 


\section{Sensitivity analysis}

For selected state variables and parameters, sensitivity analysis was performed by changing the value of the parameter by $\pm 10 \%$ of the calibrated value (while maintaining the other parameters unchanged) and observing at the effect on the state variable. Sensitivity was calculated as the difference between the values of the state variable at the highand low-parameter values divided by the calibrated value of the state variable (expressed as a percentage; Piedrahita 1987).

\section{Model validation}

The calibrated model was run with the input parameters from Experiment 3, and model output was compared with the observed field data.

\section{Results}

\section{Organic nitrogen mineralization rate (Experiment 1)}

Figure 2 shows the results of the soil incubation experiments. The regression equation of TAN concentration $(y)$ and time $(x)$ was $y=0.00104 x+0.31892$ $\left(R^{2}=0.97, n=32, P<0.01\right)$. From the difference between the final and initial TAN concentration and the volume of the water in the cylinder, it was calculated that $0.0061 \mathrm{mg} \mathrm{N}$ was produced in $63 \mathrm{~h}$. The soil

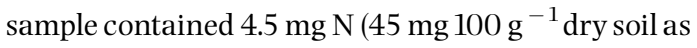
determined in Experiment 2, sample size in cylinder

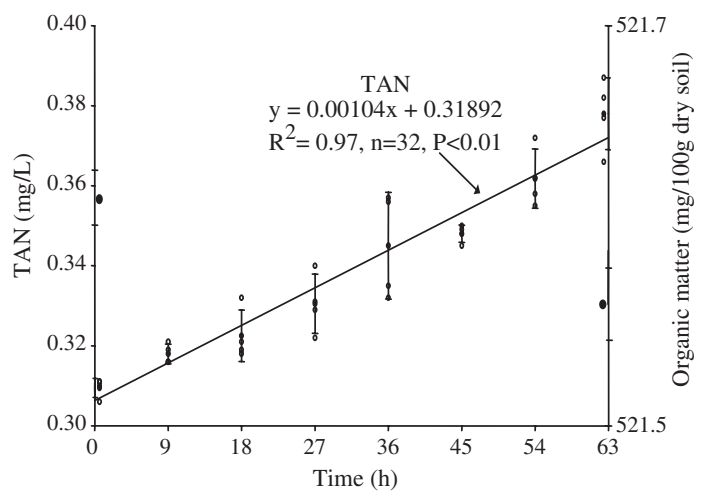

Figure 2 Organic matter concentration in soil and total ammonia nitrogen (TAN) concentrations in water during $63 \mathrm{~h}$ of incubation of sediment samples in Experiment 1 $(n=4)$.
$10 \mathrm{~g})$ and the calculated ammonification rate constant was $5.20 \times 10^{-4}$ day $^{-1}$.

The equation for the decrease in organic matter concentration $(y)$ over time $(x)$ was $y=-0.00083 x+$ 521.61. The difference between initial and final organ-

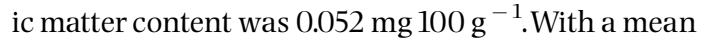

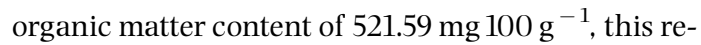
sulted in a mineralization rate constant of $3.83 \times$ $10^{-5}$ day $^{-1}$.

\section{Accumulation of organic matter in the sediments and flux of organic nitrogen species between water and sediment (Experiment 2)}

During the 84 days of Experiment 2, the fish in pond 1 grew to $238.7 \pm 63.5 \mathrm{~g}$ with a specific growth rate (SGR) of $2.27 \%$ day $^{-1}$ and a feed conversion ratio of 2.1; the fish in pond 2 grew to $330.3 \pm 103.0 \mathrm{~g}$ with a SGR of $1.77 \%$ day $^{-1}$, realizing a feed conversion ratio of 2.3. In both ponds, there were recruits of tilapia that accounted for $33.1 \%$ and $25.9 \%$ of the total final biomass respectively. These recruits were included in estimating the feed conversion ratio. The mortality of stocked fishes over the whole culture period was $32 \%$ and $27 \%$ for ponds 1 and 2 respectively.

The average concentration of nitrogen species in the water column showed values of $0.6 \pm 0.2 \mathrm{mg} \mathrm{L}^{-1}$ $\left(\mathrm{NO}_{3}^{-}-\mathrm{N}\right), 0.04 \pm 0.03 \mathrm{mg} \mathrm{L}^{-1}\left(\mathrm{NO}_{2}^{-}-\mathrm{N}\right)$ and $0.06 \pm$ $0.05 \mathrm{mg} \mathrm{L}^{-1}$ (TAN) (mean \pm S.D, $n=24$ ) for the whole period. Over time, these parameters did not show a clear increase/decrease. Total alkalinity (in meq $\mathrm{L}^{-1}$ ) decreased with time from $1.2 \pm 0.3$ to $0.4 \pm 0.6$, while chlorophyll- $a$ increased steadily from $51.9 \pm 16.5$ to $190.9 \pm 54.4 \mathrm{mg} \mathrm{m}^{-3}$ at the end of the experiment. Secchi disk visibility decreased in both ponds accordingly, with values from $>100 \mathrm{~cm}$ at the beginning of the experiment to $45 \mathrm{~cm}$ at the end.

For both ponds, the porosity of the sediment was always higher in the top layer and lower in the deeper layer (ANOVA, $P=0.0001$ ); there was an increase with time in porosity at each depth but the difference between depths did not change over time. Total ammonia nitrogen in the sediments ranged from $1.15 \pm$ 0.29 to $9.33 \pm 1.52 \mu \mathrm{gg}^{-1}$ dry sediment (Table 2), being always higher in deeper layers $(P=0.0001)$. There was a significant difference between ponds $(P=0.0046)$ and periods $(P=0.0001)$. Total nitrogen (Kjeldahl-N) was significantly different at different depths $(P=0.0001)$ and increased over time in both ponds, with values ranging from $18.34 \pm 3.83$ at the beginning of the experiment to $88.55 \pm 14.80 \mathrm{mg} \mathrm{N}$ 
Table 2 Total ammonia nitrogen (TANN) and Total nitrogen (Total N) in sediments at three different depths (mean \pm SD, $n=8$ )

\begin{tabular}{|c|c|c|c|c|c|c|c|}
\hline \multirow[b]{2}{*}{ Period } & \multirow[b]{2}{*}{ Pond } & \multicolumn{3}{|c|}{ TAN.N $\left(\mu \mathrm{g} \mathrm{g}^{-1}\right)$} & \multicolumn{3}{|c|}{ Total $\mathbf{N}\left(\mathrm{mg} 100 \mathrm{~g}^{-1}\right)$} \\
\hline & & $0-5 \mathrm{~cm}$ & $6-10 \mathrm{~cm}$ & $11-15 \mathrm{~cm}$ & $0-5 \mathrm{~cm}$ & $6-10 \mathrm{~cm}$ & $11-15 \mathrm{~cm}$ \\
\hline \multirow[t]{2}{*}{1} & 1 & $1.15 \pm 0.29$ & $1.59 \pm 0.25$ & $2.28 \pm 0.49$ & $46.25 \pm 5.52$ & $28.68 \pm 7.19$ & $21.01 \pm 4.29$ \\
\hline & 2 & $1.65 \pm 0.37$ & $2.06 \pm 0.52$ & $2.66 \pm 0.60$ & $42.56 \pm 9.41$ & $27.41 \pm 6.27$ & $18.34 \pm 3.83$ \\
\hline \multirow[t]{2}{*}{2} & 1 & $1.30 \pm 0.41$ & $1.67 \pm 0.45$ & $2.53 \pm 0.41$ & $60.18 \pm 5.12$ & $36.84 \pm 9.81$ & $28.00 \pm 3.68$ \\
\hline & 2 & $1.76 \pm 0.77$ & $2.35 \pm 0.89$ & $3.02 \pm 0.84$ & $64.02 \pm 5.75$ & $39.35 \pm 10.05$ & $30.36 \pm 5.25$ \\
\hline \multirow[t]{2}{*}{3} & 1 & $3.27 \pm 1.00$ & $4.89 \pm 1.81$ & $7.28 \pm 2.08$ & $65.82 \pm 7.63$ & $39.52 \pm 9.21$ & $30.47 \pm 8.57$ \\
\hline & 2 & $3.66 \pm 2.25$ & $6.57 \pm 1.76$ & $9.33 \pm 1.52$ & $61.59 \pm 7.71$ & $38.91 \pm 8.98$ & $28.62 \pm 6.31$ \\
\hline \multirow[t]{2}{*}{4} & 1 & $2.62 \pm 1.76$ & $4.38 \pm 2.29$ & $5.73 \pm 2.65$ & $72.95 \pm 7.42$ & $44.70 \pm 14.08$ & $34.46 \pm 11.40$ \\
\hline & 2 & $3.05 \pm 2.15$ & $5.14 \pm 2.33$ & $7.27 \pm 2.34$ & $75.07 \pm 8.79$ & $44.65 \pm 13.25$ & $34.65 \pm 9.91$ \\
\hline \multirow[t]{2}{*}{5} & 1 & $2.37 \pm 0.73$ & $3.34 \pm 0.71$ & $4.29 \pm 0.91$ & $88.55 \pm 14.80$ & $60.73 \pm 19.16$ & $53.64 \pm 16.08$ \\
\hline & 2 & $2.80 \pm 1.30$ & $3.87 \pm 1.79$ & $6.22 \pm 2.56$ & $83.86 \pm 20.51$ & $64.94 \pm 18.14$ & $50.64 \pm 7.55$ \\
\hline
\end{tabular}

Samples were collected in ponds 1 and 2 at five different periods during the growing cycle.

Table 3 Flux rate of total ammonia nitrogen (TAN) nitrite $\left(\mathrm{NO}_{2}^{-}\right)$and nitrate $\left(\mathrm{NO}_{3}^{-}\right)$estimated after laboratory incubations (mean $\pm \mathrm{SD}, n=8$ )

\begin{tabular}{lllll}
\hline & & \multicolumn{3}{l}{ Flux rate $\left(\mathbf{m g ~ N ~ m}^{-\mathbf{2}}\right.$ day $\left.^{-\mathbf{1}}\right)$} \\
\cline { 3 - 5 } Period & Pond & TAN & $\mathbf{N O}_{\mathbf{2}}^{-}$ & $\mathbf{N O}_{\mathbf{3}}^{-}$ \\
\hline 1 & 1 & $7.42 \pm 3.41$ & $-0.02 \pm 0.01$ & $-0.21 \pm 0.06$ \\
& 2 & $7.20 \pm 3.44$ & $-0.11 \pm 0.04$ & $-0.23 \pm 0.11$ \\
2 & 1 & $4.26 \pm 2.24$ & $-0.10 \pm 0.01$ & $-0.22 \pm 0.15$ \\
& 2 & $1.85 \pm 1.05$ & $-0.03 \pm 0.01$ & $-0.27 \pm 0.15$ \\
3 & 1 & $4.93 \pm 1.63$ & $-0.24 \pm 0.03$ & $-0.14 \pm 0.06$ \\
& 2 & $5.76 \pm 1.46$ & $-0.46 \pm 0.22$ & $-0.15 \pm 0.04$ \\
4 & 1 & $3.40 \pm 1.61$ & $-0.16 \pm 0.13$ & $-0.17 \pm 0.11$ \\
& 2 & $1.89 \pm 1.18$ & $-0.23 \pm 0.07$ & $-0.07 \pm 0.05$ \\
5 & 1 & $5.91 \pm 3.00$ & $-0.23 \pm 0.11$ & $-0.39 \pm 0.19$ \\
& 2 & $1.15 \pm 0.78$ & $-0.26 \pm 0.13$ & $-0.18 \pm 0.08$ \\
\hline
\end{tabular}

Negative signs indicate flux from the water column to the sediment.

$(100 \mathrm{~g})^{-1}$ dry soil at the end; ponds were not different $(P=0.7459)$. All periods, except 2 and 3, were significantly different $(P<0.05$, Table 2$)$.

$\mathrm{NO}_{2}^{-}-\mathrm{N}$ and $\mathrm{NO}_{3}^{-}-\mathrm{N}$ flux rates were always negative (net flux from the water column into the sediments) and ranged from -0.02 to $-0.46 \mathrm{mg} \mathrm{N} \mathrm{m}^{-2}$ day $^{-1}$ for nitrite, and from -0.07 to $-0.39 \mathrm{mg} \mathrm{N} \mathrm{m}^{-2}$ day ${ }^{-1}$ for nitrate. For the $\mathrm{NO}_{2}^{-}$$\mathrm{N}$ and $\mathrm{NO}_{3}^{-}-\mathrm{N}$, flux rates were not different between ponds ( $P=0.0569$ and 0.2557 respectively). The TAN flux rate was always positive (net flux from the soil to the water column) and ranged from 1.15 to $7.42 \mathrm{mg} \mathrm{N} \mathrm{m}^{-2}$ day $^{-1}$ (Table 3). The estimated firstorder rate of ammonium diffusion was in the range of 0.10 to $0.25 \mathrm{day}^{-1}$. The TAN flux rate was signifi- cantly different, both between periods $(P=0.0001)$ and ponds $(P=0.0215)$.

\section{Data collection for validation (Experiment 3)}

During the 76 days of Experiment 3, fish grew from 30 to $390 \mathrm{~g}( \pm 23.5, \mathrm{SD})$ realizing a SGR of $3.35 \%$ day $^{-1}$ and a feed conversion ratio of 2.1. Fish mortality remained below $10 \%$ in all ponds. The mean sediment organic nitrogen concentration increased from 0.3 to about $13.9 \mathrm{~g} \mathrm{~N} \mathrm{~m}^{-2}$ at the end of the experiment (Table 4).

\section{Model calibration}

The regression equation between the gross photosynthesis rate and the feed input in Experiment 1 was (Fig. 3)

$$
\begin{aligned}
& \mathrm{GPR}=0.4780 F+2.274(R=0.95, P<; 0.01) \\
& \quad \text { for } 0<F<11.5
\end{aligned}
$$

and

$$
\mathrm{GPR}=7.70 \text { for } F>11.5
$$

where GPR is the gross photosynthesis rate $\left(\mathrm{g} \mathrm{Cm}^{-2}\right.$ day $\left.^{-1}\right)$ and $F$ the feed input (g feed $\mathrm{m}^{-2}$ day ${ }^{-1}$ ).

Best results were achieved when the instant ammonification rate constants were reduced by $30 \%$ when the C:N ratio was higher than 6.625. Equations (4) and (5) can then be re-written as:

$$
\begin{aligned}
& \text { p_n_mineralization rate constant } \\
& =\text { if a_CN_ratio }>6.625 \\
& \quad \text { then } 3.64 \times 10^{-4} \text { else } 5.20 \times 10^{-4}
\end{aligned}
$$


Table 4 Organic nitrogen in sediments $\left(\mathrm{g} \mathrm{m}^{-2}\right)$ in ponds 3-6 used for the validation of the model (mean \pm SD, $n=3$ ) and overall mean $(n=12)$

\begin{tabular}{lrrrrr}
\hline Period & \multicolumn{1}{l}{ Pond 3 } & \multicolumn{1}{l}{ Pond 4 } & \multicolumn{1}{l}{ Pond 5 } & \multicolumn{1}{c}{ Pond 6 } & Mean \\
\hline 1 & $0.274 \pm 0.018$ & $0.542 \pm 0.073$ & $0.149 \pm 0.048$ & $0.355 \pm 0.032$ & $0.330 \pm 0.154$ \\
2 & $4.733 \pm 0.418$ & $4.588 \pm 0.220$ & $4.649 \pm 0.292$ & $6.034 \pm 0.224$ & $5.001 \pm 0.675$ \\
3 & $7.170 \pm 0.085$ & $7.920 \pm 0.509$ & $8.922 \pm 0.343$ & $8.312 \pm 0.254$ & $8.081 \pm 0.722$ \\
4 & $9.433 \pm 0.644$ & $9.319 \pm 0.594$ & $11.723 \pm 0.375$ & $12.118 \pm 0.097$ & $10.648 \pm 1.398$ \\
5 & $15.042 \pm 1.487$ & $13.077 \pm 0.924$ & $13.652 \pm 0.836$ & $13.737 \pm 0.498$ & $13.877 \pm 1.137$ \\
\hline
\end{tabular}

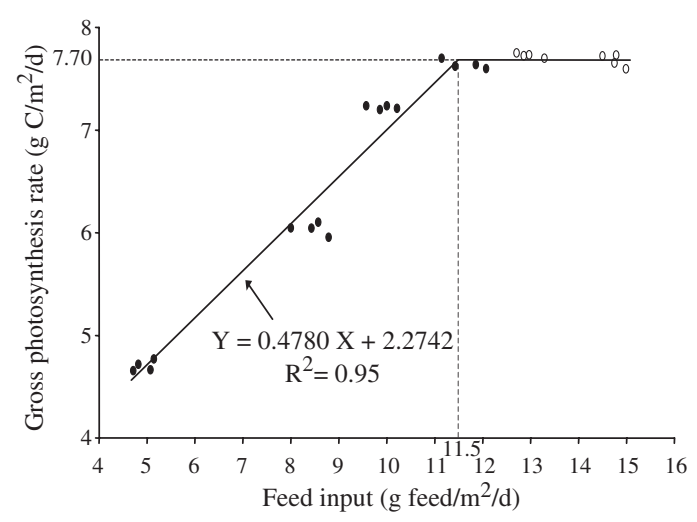

Figure 3 Relation between gross photosynthesis rate (GPR) and feed input ( $n=4$ ponds) in Experiment 1 . The continuous line represents the equation used in the model (see text). Data points used for calculating the sloping line are filled; points for the plateau are open.

and

$$
\begin{aligned}
& \text { p_c_mineralization rate constant } \\
& =\text { if a_CN_ratio }>6.625 \\
& \quad \text { then } 2.68 \times 10^{-5} \text { else } 3.83 \times 10^{-5}
\end{aligned}
$$

Calibration of the sedimentation rate constants of phytoplankton, faeces and uneaten feed resulted in values of $0.20,0.70$ and 0.90 respectively. The calibration results are presented in Fig. 4. The relative errors for sediment organic nitrogen were between +0.01 and +0.08 , and between +0.02 and +0.17 for sediment organic carbon, while the average relative errors were +0.06 and +0.10 respectively.

\section{Sensitivity analysis}

Table 5 shows the results of the sensitivity analysis. The mineralization rate constants had the strongest effect on sediment organic nitrogen and carbon (9.30 and $-9.62 \%$ respectively), while the sedimentation rate constant of phytoplankton also had an impor-

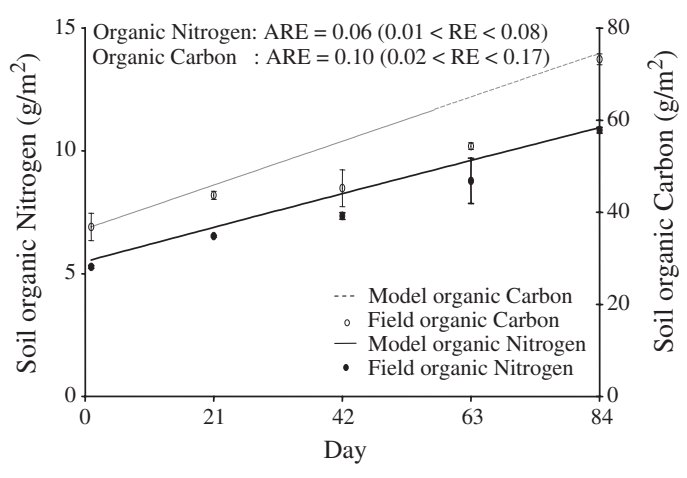

Figure 4 Simulated values and field data (average of ponds 1 and 2, Experiment 2) of organic nitrogen and carbon (after calibration).

Table 5 Sensitivity analysis - effect of increasing or de-

\begin{tabular}{|c|c|c|}
\hline \multirow[b]{2}{*}{ Parameter } & \multicolumn{2}{|c|}{ State variable } \\
\hline & $\begin{array}{l}\text { S organic } \\
\mathrm{N} \text { soil* }\end{array}$ & $\begin{array}{l}\text { S organic } \\
\text { C soil* }\end{array}$ \\
\hline P \% carbohydrate (\%) & -0.96 & -1.92 \\
\hline $\mathrm{P} \%$ protein $(\%)$ & -1.92 & -0.77 \\
\hline $\begin{array}{l}\mathrm{P} \text { feces sedimentation } \\
\text { rate constant }\left(\text { day }^{-1}\right)\end{array}$ & -1.92 & -0.76 \\
\hline $\begin{array}{l}\mathrm{P} \text { feed sedimentation } \\
\text { rate constant }(\% \text {, daily basis) }\end{array}$ & 0.13 & 0.12 \\
\hline $\begin{array}{l}\mathrm{P} \text { phytoplankton sedimentation } \\
\text { rate constant (\%, daily basis) }\end{array}$ & -6.22 & -6.20 \\
\hline $\begin{array}{l}P \text { fraction uneaten } \\
(\%, \text { from feed offered })\end{array}$ & -0.13 & 0.12 \\
\hline $\begin{array}{l}\text { P C mineralization rate } \\
\text { constant }\left(\text { day }^{-1}\right)\end{array}$ & 2.09 & -9.62 \\
\hline $\begin{array}{l}\text { P N mineralization rate } \\
\text { constant }\left(\text { day }^{-1}\right)\end{array}$ & 9.30 & -2.13 \\
\hline
\end{tabular}
creasing the indicated parameter by $10 \%$ on soil organic nitrogen and soil organic carbon*

*Numbers indicate the difference between the value of the state variable for the highest parameter and the value for the lowest parameter as a percentage of the calibrated parameter. The sign of the value used as sensitivity represents under- or overestimation, depending on whether the sign is negative or positive. 
tant effect on both nitrogen and carbon $(-6.22$ and -6.20 respectively).

\section{Model validation}

The validation of the model for sediment organic nitrogen using data from Experiment 3 (ponds 3-6) is presented in Fig. 5. The AREs for the four ponds were all 0.09-0.10, with relative errors ranging from -0.36 to +0.18 .

\section{Discussion}

The first objective of this study was to estimate the rate of mineralization of organic nitrogen in semi-intensive fish ponds. The values for the mineralization rate constants of nitrogen and carbon obtained from the incubation of pond sediment were $5.2 \times$ $10^{-4}$ day $^{-1}$ ( 0.190 year $^{-1}$ ) measuring the increase of ammonium concentration, and $3.83 \times 10^{-5} \mathrm{~d}^{-1}$ (0.014 year $^{-1}$ ) measuring the decrease of organic matter. Relating these values to the actual organic nitrogen concentrations resulted in a rate of ammonification of $7.21 \mathrm{mg} \mathrm{N} \mathrm{m}^{-2}$ day $^{-1}$. For natural systems, Billén (1978) reported an ammonification rate of $25.4 \mathrm{mg} \mathrm{N} \mathrm{m}^{-2}$ day $^{-1}$. Similarly, Blackburn and Henriksen (1983) reported rates of 24.2 and $1.45 \mathrm{mg} \mathrm{N} \mathrm{m}^{-2}$ day $^{-1}$ for aerobic and anaerobic ammonification respectively. For fish ponds, Avnimelech (1984) also reported values for not freshly deposited material, with the first-order rate constant close to 0.213 year $^{-1}$. The precision of the measurements of both ammonium and organic matter concentrations

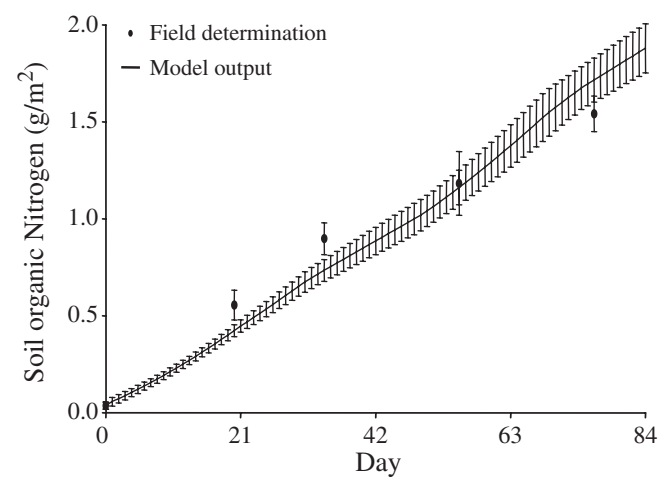

Figure 5 Field data of soil organic nitrogen and model output in stagnant Colossoma macropomum. Bars represent the standard deviation of field determinations in the ponds $(n=4)$ and the confidence limits of model simulations $(n=4)$. was just enough to detect differences during incubations; for further studies, it is recommended either to increase the incubation time or to use more sensitive measurement methods. The rate of organic nitrogen decomposition in our fish ponds was comparable with the values reported in these other studies. Oxygen concentration has an important effect on the mineralization rate of organic nitrogen but was not measured during incubations because it was considered very important not to disturb the columns. Considering the short period of incubation and the low amount of organic matter in the cores, the disolved oxygen concentration must have probably changed little.

The second objective was to measure the flux of inorganic nitrogen forms between sediments and water. TAN fluxes measured (Table 3) were similar to the values found in manured polyculture ponds (4.2 $\mathrm{mg} \mathrm{N} \mathrm{m}^{-2}$ day $^{-1}$; Schroeder 1987) and for intensive fish pond systems ( $11 \mathrm{mg} \mathrm{N} \mathrm{m}^{-2}$ day $^{-1}$; Avnimelech 1984). The directions of the fluxes show that aquaculture pond sediments are a source of reduced inorganic nitrogen (ammonium) and a sink for oxidized inorganic nitrogen (nitrate and nitrite) (Hargreaves 1998). Concentrations of dissolved nitrogen species in the water column $\left(\mathrm{NO}_{3}^{-}-\mathrm{N}, \mathrm{NO}_{2}^{-}-\mathrm{N}\right.$ and TAN) were low, and did not increase or decrease much during Experiment 2. The low concentrations were probably related to phytoplankton biomass. Throughout Experiment 2, chlorophyll- $a$ concentration increased, Secchi disk depth decreased and alkalinity decreased simultaneously. Dissolved inorganic nitrogen uptake by phytoplankton in ponds is the primary pathway of nitrogen removal, and in semi-intensive aquaculture ponds, a dense phytoplankton population often develops (Hargreaves 1998).

The third objective was to quantify the amount of organic matter accumulating in the sediment. Total nitrogen (Kjeldahl-N) in the sediment indeed increased with time (Table 2). Nitrogen recovery (\% of $\mathrm{N}$ input found in the bottom sediments) was $15.5 \pm 2.9 \%$ in pond 1 and $14.6 \pm 5.2 \%$ in pond 2 . Similar results were found in an intensive eel pond (8-13\%; Chiba 1986) and in semi-intensive shrimp ponds (15-22\%; Hopkins et al. 1994).

Soil porosity was always higher in the top layers and increased with time due to the looseness of fresh organic matter that accumulates in the bottom during the growing cycle (Tucker 1985). For systems with high biological activity (such as fish ponds), the high porosity is particularly important because resuspension enhances the aeration of the upper layers of soil. 
This facilitates the exchange of pore water with pond water (Boyd 1995), stimulates the decomposition of organic matter and increases the flux of nutrients towards the water column (Henriksen, Hansen \& Blackburn 1980; Blackburn \& Henriksen 1983).

Total ammonia nitrogen in sediments ranged from

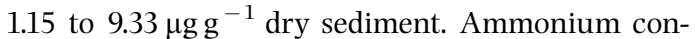
centration was low at the sediment-water interface (0-5 sediment layer) and increased with depth. Total nitrogen (consisting mainly of organic nitrogen forms) was higher in the surface layer and decreased with depth. This opposite trend of TAN and organic matter with depth was found in other studies of fish pond sediments (e.g. Avnimelech \& Lacher 1979; Shilo \& Rimon 1982) and is caused by the constant addition of organic matter by sedimentation from the water column and the simultaneous ammonification with a flux of ammonia to the water column; another reason of the gradient found is the lower availability of oxygen found in deeper layers.

With regard to the fourth objective to construct a simulation model of organic matter deposition and decomposition in fish ponds, a good fit between simulated and observed concentrations of sediment organic carbon and nitrogen was achieved in the calibrated model, with relative errors lower than 0.17 and average relative errors of $6 \%$ for organic nitrogen and $10 \%$ for organic carbon (Fig. 4). During validation with the independent data of Experiment 3 , the average relative errors for the simulation of organic nitrogen remained below $10 \%$ (Fig. 5). Although the datasets for calibration and validation were substantially different (notably with regard to pond size and fish species), the model performs well under different conditions.

The sedimentation rate constants of the three organic matter sources were estimated through model calibration, and gave good results in the validation. $90 \%$ from the uneaten feed, $70 \%$ of the faeces and $20 \%$ of the phytoplankton standing crop settles to the pond bottom every day. Sinking rates, calculated using Stoke's equation, take into consideration the volume and density of the particles, the density and the viscosity of the medium, and the acceleration due to gravity (Jørgensen 1989). Because faeces and feed have higher densities, volume and weight than planktonic cells, higher sinking rates are expected. For the sedimentation rate constant of phytoplankton, Schroeder et al. (1991) reported that as much as $50 \%$ of the algal standing crop settles to the sediment surface each day. Our lower estimate of $20 \%$ is in accordance with Larocque, Mazumder, Proulx, Lean and Pick (1996), who reported a daily settlement of $2-16 \%$ of the epilimnetic algal biomass for a temperate lake.

The sensitivity analysis showed that both soil organic nitrogen and soil organic carbon are strongly affected by its respective mineralization rate. In the original model, the mineralization rate of settled organic nitrogen and carbon only depended on its own concentration and did not take into account the proportion of carbon and nitrogen in the organic matter ( $\mathrm{C}: \mathrm{N}$ ratio). In the present model, nitrogen and carbon mineralization rates were dependent on the C:N ratio. The assumption that the $\mathrm{C}: \mathrm{N}$-ratio of the organic matter plays a key role in its decomposition rate has been documented earlier (e.g. van der Borght, Wollast \& Billén 1977; Almazán \& Boyd 1978; Blackburn \& Henriksen 1983; Boyd 1995), but little quantitative information on the relationship between C:N ratio and mineralization exists. The $30 \%$ reduction in mineralization of both organic $\mathrm{C}$ and organic $\mathrm{N}$ with a C:N ratio above 6.625 was based on the $\mathrm{C}: \mathrm{N}$ ratio in the bacteria. The initial C: $\mathrm{N}$ ratio of 6.625 was selected because this is the ratio in algal matter, which was assumed to be the largest fraction of the organic matter accumulating in the sediment. The mineralization rates will be higher close to the ratio of 6 and will decrease far above 6 . A boundary level of 6.625 was arbitrarily assumed. This assumption was acceptable because the $\mathrm{C}: \mathrm{N}$ ratio varied in a narrow range (6.2-7, Fig. 6); when the $\mathrm{C}: \mathrm{N}$ ratio increases above 7 , the mineralization rate will decline further. For studies outside this range, the relation should be studied in more detail.

Although not considered in the present work, the suspension/resuspension of sediments plays an important role in the transfer of chemical components between the water column and the sediment. Resuspension is an important process in fish ponds (Beveridge, Wahab \& Dawan 1994; Avnimelech, Kochva \& Hargreaves 1999), and has an effect on the amount of organic matter that accumulates in the sediments. Avnimelech and colleagues (1999) found that resuspended material accounted for approximately 60$90 \%$ of the total sedimentation flux. Because in this study resuspension was not taken into account, the apparent rate of decomposition was calculated. Incorporation of suspension/resuspension into the model could represent a major improvement and should be incorporated in future model studies.

With the information from this study, the comprehensive pond model (Jiménez-Montealegre et al. 2002) can be improved. The sedimentation rate of 


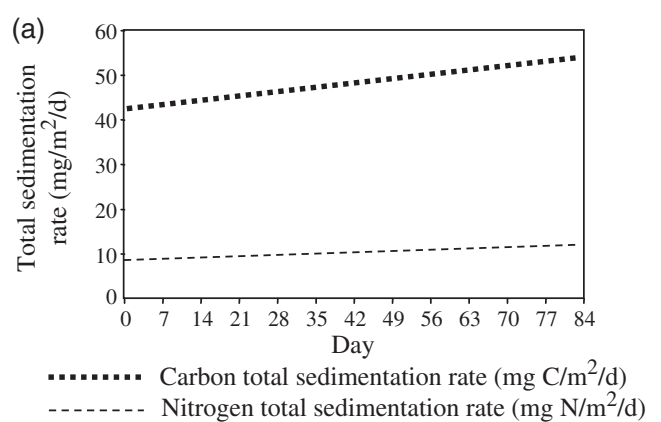

(b)

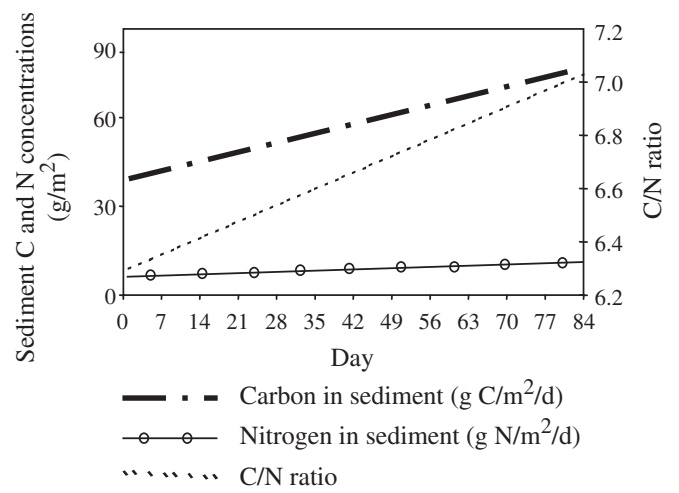

Figure 6 Model output. (a) Comparison of total sedimentation rates for carbon and nitrogen. (b) $\mathrm{C}$ and $\mathrm{N}$ concentrations in sediments and C: $\mathrm{N}$ ratio.

phytoplankton and the mineralization rates were the most important ones in determining the accumulation of organic nitrogen and carbon in the pond bottom. Sedimentation increased steadily, as it was related to the feeding rate and feces production (both increasing with increasing fish biomass) and primary production (also increasing with time). Decomposition of organic matter is governed by the decomposition rates of organic nitrogen and carbon. Because organic nitrogen is decomposed more rapidly than organic carbon, as shown by the different values of the decomposition rate constants, the $\mathrm{C}: \mathrm{N}$ ratio of the sediment increases with time. This leads to even slower decomposition rates and enhances accumulation of (more and more refractory) organic matter in the sediment (Fig. 6).

Management measures to avoid accumulation would include the reduction of sedimentation of organic matter, e.g. by prevention of feed losses and increasing the digestibility of diets. Another possibility would be to harvest primary production before it can settle to the sediment using a herbivorous fish species (although this would create another flux of faecal matter to the sediments). Results from studies on the use of substrates in aquaculture ponds show that particulate organic matter may be trapped by periphyton (van Dam, Beveridge, Azim \& Verdegem 2002). It may also be possible to manipulate the $\mathrm{C}: \mathrm{N}$ ratio of sediments by changing the composition of feeds (Avnimelech et al. 1999), thus preventing the decomposition process from slowing down. The mechanisms explored in the current model will be incorporated in a more comprehensive simulation model that includes primary productivity, fish growth, sedimentation and resuspension and decomposition processes, and will be used to evaluate different pond management strategies.

\section{Acknowledgments}

This study was partly financed by the European Commission under the INCO-DC program (Contract No. IC18-CT97-0202), and partly financed by the 'Programa UNA-LUW/Ciencias Acuáticas', a Cooperation Project between the Escuela de Ciencias Biológicas, Universidad Nacional, Heredia, Costa Rica and the Fish Culture and Fisheries Group of the Wageningen University and Research Center, the Netherlands. Prof. Dr E. A. Huisman and Prof. Dr Y. Avnimelech are thanked for their valuable comments and suggestions.

\section{References}

APHA (American Public Health Association, American Water Works Association and Water Pollution Control Federation) (1989) Standard Methods for the Examination of Water and Wastewater, 17th edn. APHA, Washington, DC, USA.

Alexander M. (1961) Introduction to Soil Microbiology. John Wiley and Sons, New York, USA.

Almazán G. \& Boyd C.E. (1978) Effects of nitrogen levels on rates of oxygen consumption during decay of aquatic plants. Aquatic Botany 5, 119-126.

Avnimelech Y. (1984) Reactions in fish pond sediments as inferred from sediment cores data. In: Research on Aquaculture, Proceedings of the Second Seminar of the GermanIsraeli Cooperation in Aquaculture Research, Special Publication No. 8 (ed. by H. Rosenthal \& S. Sarig), pp. 41-54. European Mariculture Society, Bredene, Belgium. Avnimelech Y. \& Lacher M. (1979) A tentative nutrient balance for intensive fish ponds. Bamidgeh 31, 3-8.

Avnimelech Y., Lacher M., Raveh A. \& Zur O. (1981) A method for the evaluation of conditions in a fish pond sediment. Aquaculture 23, 361-365.

AvnimelechY., Kochva M. \& Hargreaves J.A. (1999) Sedimentation and resuspension in earthen fish ponds. Journal of the World Aquaculture Society 30, 401-409. 
Ayub M., Boyd C.E. \& Teichert-Coddington D. (1993) Effects of urea application, aeration, and drying on total carbon concentrations in pond bottom soils. Progressive Fish-Culturist 55, 210-213.

Barat S. \& Jana B.B. (1987) Effect of farming management on the distribution pattern of ammonification rates, protein mineralizing and ammonifying bacterial population in experimental culture tanks. Bamidgeh 39, 120-132.

Beveridge M.C.M.,Wahab A. \& Dewan S. (1994) Effects of daily harrowing on pond soil and water nutrient levels and on Rohu fingerlings production. Progressive Fish-Culturist 56, 282-287.

Billén G. (1978) A budget of nitrogen recycling in North Sea sediments off the Belgian coast. Estaurine and Costal Marine Science 7, 127-146.

Blackburn T.H. \& Henriksen K. (1983) Nitrogen cycling in different types of sediments from Danish waters. Limnology and Oceanography 28, 477-493.

Boyd C.E. (1990) Water Quality in Ponds for Aquaculture. Alabama Agricultural Experiment Station, Auburn University, AL, USA.

Boyd C.E. (1995) Bottom Soils, Sediment, and Pond Aquaculture. Chapman \& Hall, New York, USA.

van der Borght J.P., Wollast R. \& Billén G. (1977) Kinetic models of diagenesis in disturbed sediments. Part 2: nitrogen diagenesis. Limnology and Oceanography 22, 794-803.

Boynton W.R., Kemp W.M. \& Osborne C.G. (1980) Nutrient fluxes across the sediment-water interface in the turbid zone of a coastal plain estuary. In: Estuarine Perspectives (ed. by V.S. Kennedy), pp. 93-109. Academic Press, New York, USA.

Brannon J.M., Chen R.L. \& Gunnison D. (1985) Sediment-water interactions and mineral cycling in reservoirs. In: Microbial Processes in Reservoirs (ed. by D. Gunnison), pp. 121-134. Dr W. Junk Publishers, Dordrecht, the Netherlands.

Brown J.R., Gowen R.J. \& McLusky D.S. (1987) The effects of salmon farming on the benthos of a Scottish sea loch. Journal of Experimental Marine Biology and Ecology 109, 39-51.

Chiba K. (1986) The cycle of nitrogen, carbon and phosphorus in an eel culture pond. In:The First Asian Fisheries Forum (ed. by J.L. Maclean, L.B. Dizon \& L.V. Hosillos), pp. 31-34. Asian Fisheries Society, Manila, Philippines.

van Dam A.A. \& Penning de Vries F.W.T. (1995) Parameterization and calibration of a model to simulate effects of feeding level and feed composition on growth of Oreochromis niloticus (L.) and Oncorhynchus mykiss (Walbaum). Aquaculture Research 26, 415-425.

van Dam A.A., Beveridge M.C.M., Azim M.E. \& Verdegem M.C.J. (2002) The potential of fish production based on periphyton. Reviews in Fish Biology and Fisheries 12, 1-31.

Fallon R.D. \& Brock T.D. (1979) Decomposition of bluegreen algae (cyanobacterial) blooms in Lake Mendota, Wisconsin. Applied and Environmental Microbiology 37, 820-830.

Foree E.G. \& McCarty P.L. (1970) Anaerobic decomposition of algae. Environmental Science and Technology 4, 842-849.
Gomez K.A. \& Gomez A.A. (1984) Statistical Procedures for Agricultural Research, 2nd edn. John Wiley and Sons, New York.

Guerin-Ancey O. (1976) Etude experimentale de l'excretion azotee du bav (Dicentrarchus labrax) en cours de croissance et l'effects du genne sur l'excretion d'amoniac et d'uree. Aquaculture 9, 187-194.

Hargreaves J.A. (1998) Nitrogen biogeochemistry of aquaculture ponds. Aquaculture 166, 181-212.

Harrison W.G. (1978) Experimental measurements of nitrogen remineralization in coastal waters. Limnology and Oceanography 23, 684-694.

Henriksen K., Hansen J.I. \& Blackburn T.H. (1980) The influence of benthic infauna on exchange rates of inorganic nitrogen between sediment and water. Ophelia (Suppl. 1), 249-256.

Hopkins J.S., Sandifer P.A. \& Browdy C.L. (1994) Sludge management in intensive pond culture of shrimp: effect of management regime on water quality, sludge characteristics, nitrogen extinction, and shrimp production. Aquaculture Engineering 13, 11-30.

Jiménez-Montealegre R.,Verdegem M.C.J., van Dam A. \& Verreth J.A.J. (2002) Conceptualization and validation of a dynamic model for the simulation of nitrogen transformations and fluxes in fish ponds. Ecological Modelling 147, 123-152.

Jørgensen S.E. (1989) Sedimentation. In: Mathematical Submodels in Water Quality Systems, Developments in Environmental Modelling 14 (ed. by S.E. Jørgensen \& M.J. Gromiec), pp. 109-124. Elsevier, Amsterdam, the Netherlands.

Kaushik S.J. (1980) Influence of nutritional status on the daily patterns of nitrogen excretion in the carp (Cyprinus carpio L.) and the rainbow trout (Salmo gairdneri). Reproductive Nutrition and Development 20, 1557-1565.

Krom M.D. \& Berner R.A. (1980) The diffusion coefficients of sulfate, ammonium and phosphate ions in anoxic marine sediments. Limnology and Oceanography $\mathbf{2 5}$, 327-337.

Krom M.D., Porter C. \& Gordin H. (1985) Nutrient budget of a marine fish pond in Eilat, Israel. Aquaculture 51, 65-80.

Larocque I., Mazumder A., Proulx M., Lean D.R.S. \& Pick F.R. (1996) Sedimentation of algae: relationship with biomass and size distribution. Canadian Journal of Fisheries and Aquatic Science 53, 1133-1142.

Lovell T. (1988) Nutrition and Feeding of Fish. Van Nostrand Reinhold, New York, USA.

van der Meer M.B., van Herwaarden H. \& Verdegem M.C.J. (1997) Effect of number of meals and frequency of feeding on voluntary feed intake of Colossoma macropomum $(\mathrm{Cu}-$ vier). Aquaculture Research 28, 419-432.

Phillips M.J., Beveridge M.C.M. \& Muir J.F. (1985) Waste output and environmental effects of rainbow trout cage culture. International Council for the Exploration of the Sea (ICES) 21, 16 pp.. 
Piedrahita R.H. (1987) Sensitivity analysis for an aquaculture pond model. In: Automation and Data Processing in Aquaculture, Proceedings of the IFAC Symposium, 18-21 August 1986, Trondheim, Norway (ed. by J.G. Balchen), pp. 119-123.

Porter C., Krom M.D., Robbins M.D., Bricknell M.G. \& Davidson A. (1987) Ammonia excretion and total N budget for gilthead seabream (Sparus aurata) and its effect on water quality conditions. Aquaculture 66, 287-298.

Raveh A. \& Avnimelech Y. (1972) Potentiometric determination of soil organic matter. Soil Science Society of America Proceedings 36, 967.

Schroeder G.L. (1987) Carbon and nitrogen budgets in manured fish ponds on Israel's coastal plain. Aquaculture 62 , 259-279.

Schroeder G.L., Alkon A. \& Laher M. (1991) Nutrient flow in pond aquaculture systems. In: Aquaculture and Water Quality (ed. by D.E. Brune \& J.R. Tomasso), pp. 498-505. World Aquaculture Society, Baton Rouge, LA, USA.

Seitzinger S.P. (1988) Denitrification in freshwater and coastal marine ecosystems. Ecological and geochemical significance. Limnology and Oceanography 33, 702-724.
Sudo R., Aiba H.O.S. \& Mori T. (1978) Some ecological observations on the decomposition of periphytic algae and aquatic plants. Water Research 12, 177-184.

Shilo M. \& Rimon A. (1982) Factors which affect the intensification of fish breading in Israel. 2. Ammonia transformation in intensive fish ponds. Bamidgeh $\mathbf{3 4}$, 101-114.

Thorpe J.E., Talbot C., Miles M.S., Rawlings C. \& Keay D.S. (1990) Food consumption in 24 hours by Atlantic salmon (Salmo salar L) in a sea cage. Aquaculture 90, 41-47.

Tucker C.S. (1985) Organic matter, nitrogen, and phosphorus content of sediments from channel catfish Ictalurus punctatus. Research report 10, Mississippi Agricultural Forestry Experiment Station, Mississippi State University, Stoneville, MS, USA.

Valdés D. \& Real E. (1994) Ammonium, nitrite, nitrate and phosphate fluxes across the sediment-water interface in a tropical lagoon. Ciencias Marinas 20,65-80.

Visscher P.T. \& Duerr E.O. (1991) Water quality and microbial dynamics in shrimp ponds receiving bagassebased feed. Journal of the World Aquaculture Society 22, 65-76. 